\title{
The correlation between renal transplantation and liver carcinoma: a meta-analysis
}

\author{
Hong Yongzhi ${ }^{1, *}, \mathrm{Xu} \mathrm{Min}^{2, *}, \mathrm{Yu} \mathrm{Bo}^{3}$, Chen Pin ${ }^{3, * *}$ and Shi Xueqiang ${ }^{3}$ \\ ${ }^{1}$ Department of Neurosurgery, The First Affiliated Hospital of Nanjing Medical University, Nanjing 210029, Jiangsu Province, \\ China \\ ${ }^{2}$ Department of Neurosurgery, Kunshan Hospital of Traditional Chinese Medicine, Kunshan Affiliated Hospital of Nanjing \\ University of Chinese Medicine, Kunshan 215300, Jiangsu Province, China \\ ${ }^{3}$ Department of Neurosurgery, Clinical Medical College of Yangzhou University, Subei People's Hospital of Jiangsu province, \\ Yangzhou 225001, Jiangsu Province, China \\ *These authors have contributed equally to this work and considered as co-first authors \\ ${ }^{* *}$ First corresponding author \\ Correspondence to: Chen Pin, email: chenpin1987@126.com \\ Shi Xueqiang, email: yzsxq1999@sohu.com
}

Keywords: meta-analysis, renal transplantation, liver carcinoma, chronic virus hepatitis, anti-virus

Received: March 07, $2017 \quad$ Accepted: May 04, $2017 \quad$ Published: July 22, 2017

Copyright: Yongzhi et al. This is an open-access article distributed under the terms of the Creative Commons Attribution License 3.0 (CC BY 3.0), which permits unrestricted use, distribution, and reproduction in any medium, provided the original author and source are credited.

\section{ABSTRACT}

Objective: Much of the related researches have reported the correlation between renal transplantation and different tumors in the post transplant recipients. However, there are not exact essays revealed that renal transplantation is definite causation for liver carcinoma, thus we systematically evaluated the association between renal transplantation and the risk of liver carcinoma in this meta-analysis from all available researches.

Methods: All useful data were collected through searching of PubMed and Web of Science until the date of 31 September 2015. Random-effects model were adopted to calculate the standardized incidence ratio and $95 \%$ confidence interval (CIs) of the risk of liver carcinoma among renal transplant recipients. Other statistical analyses like heterogeneity tests, sensitivity analysis and publication bias were also performed in this meta-analysis.

Results: Among 17,4256 kidney transplant cases and 25,6736 patients-years observation, 9136 post-transplant cancers were diagnosed. We identified a 2.08fold higher standardized incidence rate (SIR) (95\% confidence interval (CI): 1.243.47, $P=0.005$ ) of liver carcinoma following renal transplantation compared with the general population. Observation and publication bias were not observed in this study.

Conclusion: This study suggested that the risk of liver carcinoma among renal transplant recipients with chronic hepatic disease is higher than general population. Such results alert clinical doctors the importance of anti-virus therapy with chronic virus hepatitis and enough attention of periodic liver screening with chronic liver diseases in renal transplant recipients.

\section{INTRODUCTION}

Chronic kidney disease (CKD) is quite a common disease around the world, its etiology from infectious disease to emerging diseases especially hypertension and diabetes [1-3]. CKD increases a large burden for our society for its highly associated morbidity and mortality, mainly elevated cardiovascular system diseases $[4,5]$. In clinical therapy, there are different related therapy ways 
during CKD patients' different period, the most common therapy ways like dialysis and renal transplantation.

Renal transplantation is regarded as the therapeutic option of choice in the end-stage renal failure [6]. Initially, for transplant recipients, the de novo malignancy is the only sideline of this population, since tumor-specific mortality is not the main reason of the population [7]. However, with the judicious use of better immunosuppressive agents, it dramatically decreases the incidence of acute graft rejection and long-term outcome can be enhanced [8,9]. At the same time, it increases the risk of variety of new malignancies. The most common of these malignancies are skin cancers and lymphomas, followed by Kaposi, sarcoma, lip, cervical, perineal, renal, hepatocellular carcinomas and other sarcomas $[10,11]$.

Hepatocellular carcinoma (HCC) is also a common tumor worldwide, it's popularity has related geographic differences. Epidemiology revealed that areas with high incidence include Africa, in Asia especially southeastern countries (Korea, Hong Kong, Thailand), however, in majority areas of China and Japan. Its main risk factors are hepatitis virus infection like hepatitis $B$ and hepatitis $C$, the other susceptible factors are alcohol consumption, aflatoxin B1 intake and other associated congenital diseases [12].

Some studies have showed the increased risk of liver carcinoma after renal transplantation [13, 14]. However, not all studies showed similar association around the world, it may relate to the geography and population difference. Because of differences in study design, sample selection, sample size, follow-up period, and population and geographic differences, the connection between renal transplantation and liver carcinoma remains unclear. So this meta-analysis, which included all relevant studies on liver carcinoma and renal transplantation, was performed to clarify whether the total standardized incidence rate (SIR) of liver carcinoma is higher following renal transplantation than in the general population, which might be helpful in determining whether conclusive recommendations for liver cancer screening in renal transplantation recipients are needed.

\section{RESULTS}

\section{Study characteristics}

A total of 9 studies met our inclusion criteria [13, 15-22]. These 9 articles, which included 17,4256 renal transplantation recipients in 25,7206 patients, evaluated whether the total SIR for liver cancer was higher in renal transplant recipients than in the general population. An outline for the selection process of identified studies is presented in Figure 1. The main characteristics of the studies and their details are listed in Table 1. All the studies were retrospective, and the largest study had 12,0654 renal transplant recipients. These related studies were based on patients in several countries, including Italy, China, Sweden, the USA, the UK, Canada and Japan.
Table 2 shows summary of the included studies in our analysis with details of the studies. As noted, the 257206 renal transplant recipients were included in this analysis were followed up for a total of 256736 personyears, with a mean follow-up duration of 7.6125 years (range: 4.8 - 16.0 years). The mean age at transplantation were 44.77 (range: 41.5 - 47.3) years old. Of the 9136 cases that developed cancers and hematological malignancies, this meta-analysis identified 185 cases of liver cancer compared to 84.12 expected cases.

\section{Evidence analysis}

This meta-analysis for the SIR for liver cancer suggested a significantly increased risk compared to the common population ( $\mathrm{SIR}=2.08,95 \% \mathrm{CI}$ : 1.24 3.47; $\mathrm{P}=0.005$; Table 3). Figure 2 shows forest plots for individual and overall RR measures. There was heterogeneity $\left(I^{2}=89.2 \%, \mathrm{P}_{\text {heterogeneity }}=0.000\right)$ in the pooled analysis.

Sensitivity analysis assessed the influence of an individual study on the pooled RR by omitting one study and re-analyzing the results. Our sensitivity analysis indicates the omission of any of the studies led to changes in estimates between $1.844(95 \% \mathrm{CI}=1.209-2.814)$ and $2.428(95 \% \mathrm{CI}=1.579$ - 3.733; Table 4). In assessing the association of renal transplantation with the risk of liver cancer risk, we found that no individual altered the significance of the RRs, suggesting the stability and reliability of the overall results (Figure 3). With limited information available, we could not detect any sources contributing to the substantial heterogeneity. Potential publication bias of the studies was assessed using Funnel plots and Begg's and Egger's tests. Funnel plot asymmetry was not observed. Publication bias was not evident $(\mathrm{t}=-0.79, \mathrm{p}=0.457)$ (Figure 4).

\section{DISCUSSION}

Our collected data suggests that the increased risk of developing liver cancer in renal transplantation compared with general population $(\mathrm{SIR}=2.077,95 \%$ $\mathrm{CI}=1.244-3.471, \mathrm{P}=0.005$ ). Tumors such as NHL and Kaposi's carcinoma, which are rare in the general population, however, are encountered more frequently in solid organ transplantation recipients [23]. Liver carcinoma prevails around the world, the difference of the prevalence and mortality exists due to the genetic background and regional environmental difference. Among the solid organ transplant recipients (e g: kidney transplantation recipients), its incidence rate also enhanced with the organ transplantation $[13,17,22]$. In this metaanalysis, our collected data provide further evidence that renal transplantation recipients are at more risk of liver carcinoma than the general population.

The exact mechanisms of the oncogenesis in renal transplantation recipients are still unknown. Several 
possible related factors had been proposed. One hypothesis is that cancers result from related viral infection(hepatitis $B$ virus or hepatitis $C$ virus related) and another is reduced immune surveillance against a variety of non-viral tumor antigens [24]. For a part of renal transplant recipients, they were also chronic B virus carrier at the same time and this figure were similar to the local general population [13]. Organ transplant recipients are vulnerable to viral infection or reactivation of latent infection because the initiation of immunosuppressive agents may promote the unchecked viral replication. In this situation that hepatitis virus infected patients with renal transplant, physicians should check virus quantitative at regular intervals, then take corresponding efforts of anti-virus therapy. At the same time, clinical doctors should attach great importance on immunosuppressive agents treatment period and dosage, in order to prevent hepatitis virus reactivation among patients with viral hepatitis. For the end-stage kidney disease (ESKD) patients, dialysis is one important therapy and it can prolong patients' media kidney transplant age. A great proportion of patients are usually infected before renal transplantation while using

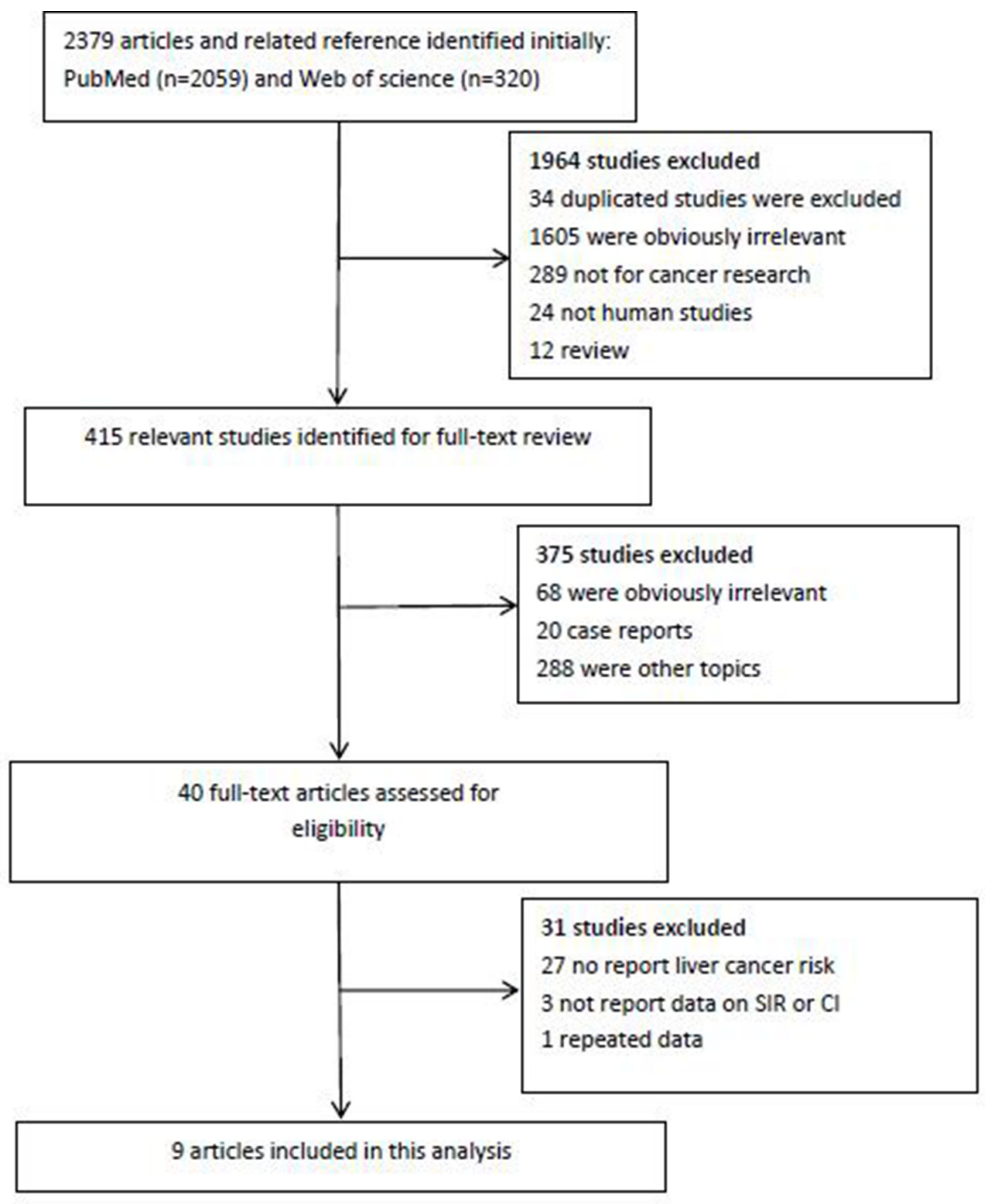

Figure 1: Flow chart of literature search and study selection. 
Table 1: Summary of studies included in the analysis

\begin{tabular}{|c|c|c|c|c|c|c|}
\hline Study & Year & $\begin{array}{c}\text { Type of } \\
\text { transplant }\end{array}$ & Data source & Geographicorigin & $\begin{array}{l}\text { Number of } \\
\text { patients (n) }\end{array}$ & $\begin{array}{c}\text { Number of } \\
\text { kidneytransplant } \\
\text { cases }\end{array}$ \\
\hline Piselli & 2013 & Kidney & Italian KT centre & Italy & 7217 & 7299 \\
\hline Cheung & 2012 & Kidney & Hong Kong Renal Registry & China & 4674 & 4895 \\
\hline Krynitz & 2012 & multiorgan & $\begin{array}{c}\text { Swedish National Patient } \\
\text { Register }\end{array}$ & Sweden & 10476 & 7952 \\
\hline $\mathbf{L i}$ & 2012 & Kidney & $\begin{array}{c}\text { Taiwan National Health } \\
\text { InsuranceResearch } \\
\text { Database (NHIRD) }\end{array}$ & China & 4716 & 4716 \\
\hline Engels & 2011 & multiorgan & $\begin{array}{l}\text { Scientific Registry of } \\
\text { Transplant Recipients }\end{array}$ & U.S. & 175732 & 120654 \\
\hline Collett & 2010 & multiorgan & UK Transplant Registry & UK & 37617 & 25104 \\
\hline Serraino & 2007 & multiorgan & No mention & Italy & 2875 & 1892 \\
\hline Villeneuve & 2007 & multiorgan & Canadian cancer registry & Canada & 11155 & 11391 \\
\hline Hoshida & 1997 & multiorgan & Multicentre Japan & Japan & 2744 & 1744 \\
\hline Total & - & - & - & - & 257206 & 174256 \\
\hline
\end{tabular}

Table 2: Demographic details of patients in the included studies

\begin{tabular}{|c|c|c|c|c|c|c|c|c|}
\hline Study & Year & $\begin{array}{l}\text { Length of } \\
\text { follow-up } \\
\text { time }\end{array}$ & $\begin{array}{l}\text { Number of } \\
\text { all cancers } \\
\text { (n) in kidney } \\
\text { transplant } \\
\text { cases }\end{array}$ & $\begin{array}{c}\text { Mean } \\
\text { follow-up } \\
\text { time(years) }\end{array}$ & $\begin{array}{c}\text { Patient-years } \\
\text { (years) }\end{array}$ & $\begin{array}{c}\text { Mean age at } \\
\text { transplantation } \\
\text { (years) }\end{array}$ & $\begin{array}{l}\text { Number of } \\
\text { expected } \\
\text { cases of } \\
\text { liver cancer }\end{array}$ & $\begin{array}{c}\text { Number } \\
\text { of } \\
\text { identified } \\
\text { cases } \\
\text { of liver } \\
\text { cancers }\end{array}$ \\
\hline Piselli & 2013 & 1997-2009 & 395 & 5.5 & 39598.0 & - & 9.40 & 4 \\
\hline Cheung & 2012 & $1972-2011$ & 299 & 8.2 & 40246 & 47.3 & 7.92 & 20 \\
\hline Krynitz & 2012 & $1970-2008$ & 2774 & 5.1 & 93432 & - & - & 20 \\
\hline $\mathbf{L i}$ & 2012 & $1997-2008$ & 320 & 4.8 & 22556 & 41.5 & 11.80 & 60 \\
\hline Engels & 2011 & 1987-2008 & - & - & - & - & 44.50 & 48 \\
\hline Collett & 2010 & $1980-2007$ & 4420 & 16.0 & - & - & 7.80 & 19 \\
\hline Serraino & 2007 & - & 104 & 6.5 & 6931 & 45.50 & - & 6 \\
\hline Villeneuve & 2007 & 1981-1998 & 778 & 7.4 & 81237 & - & 2.70 & 5 \\
\hline Hoshida & 1997 & 1970-1995 & 46 & 7.4 & 12982 & - & - & 3 \\
\hline Total & - & - & 9136 & 7.6125 & 256736 & 44.77 & 84.12 & 185 \\
\hline
\end{tabular}

hemodialysis facilities. Previous studies demonstrated that hepatitis $\mathrm{C}$ has a wide range of prevalence among renal transplant recipients living in different countries [25, 26]. Some important factors that have an impact on $\mathrm{HCV}$ infection in subjects receiving hemodialysis facilities are as follows: race, geographic origin of the recipients [27], type of dialysis [28-30], number of blood transfusion [27,
31], history of organ transplantation [32] and hepatitis B virus co-infection. In Italy, among dialysis patients, the prevalence with HBV and or with $\mathrm{HCV}$ is high [33]. Because of renal failure, some dialysis patients need some blood transfusion, the potential reason for this situation is due to the lack of erythropoietin which is mainly produced by the kidney [34], then entire body manifest a series of 
Table 3: Overall SIR and 95\% CI in our meta-analysis

\begin{tabular}{lcccc}
\hline \multirow{2}{*}{ Study } & Year & SIR & \multicolumn{2}{c}{ 95\% Confidence intervals } \\
\cline { 3 - 4 } Piselli & 2013 & & LCI & UCI \\
Cheung & 2012 & 0.40 & 0.10 & 3.91 \\
Krynitz & 2012 & 2.53 & 1.63 & 4.10 \\
Li & 2012 & 2.70 & 1.60 & 6.42 \\
Engels & 2011 & 5.07 & 3.89 & 1.43 \\
Collett & 2010 & 1.08 & 0.80 & 3.80 \\
Serraino & 2007 & 2.40 & 1.50 & 8.70 \\
Villeneuve & 2007 & 4.00 & 1.50 & 4.30 \\
Hoshida & 1997 & 1.80 & 0.60 & 3.36 \\
Combined & - & 1.36 & 0.24 & $\mathbf{3 . 4 8 8}$ \\
\hline
\end{tabular}

symptoms of anemia like breathlessness, dizziness, poor appetite and decreased exercise tolerance. Some essays reported that hepatitis $\mathrm{C}$ is a major cause of transfusion associated hepatitis and also a leading cause of chronic liver disease in transplant recipients $[35,36]$. It is also a cause of chronic hepatitis in approximately $10 \%$ of all renal transplant recipients [35]. In order to prevent the occurrence of this phenomenon, regarding to the patients of non-infected hepatitis virus recipients, medical organization should pay much attention to the medical facilities. In addition to hepatitis $\mathrm{C}$ virus, hepatitis $\mathrm{B}$ virus (HBV) is a well-known oncogenic virus and the main risk for hepatocellular carcinoma development. For hepatitis B virus (HBV) infected patients, occult

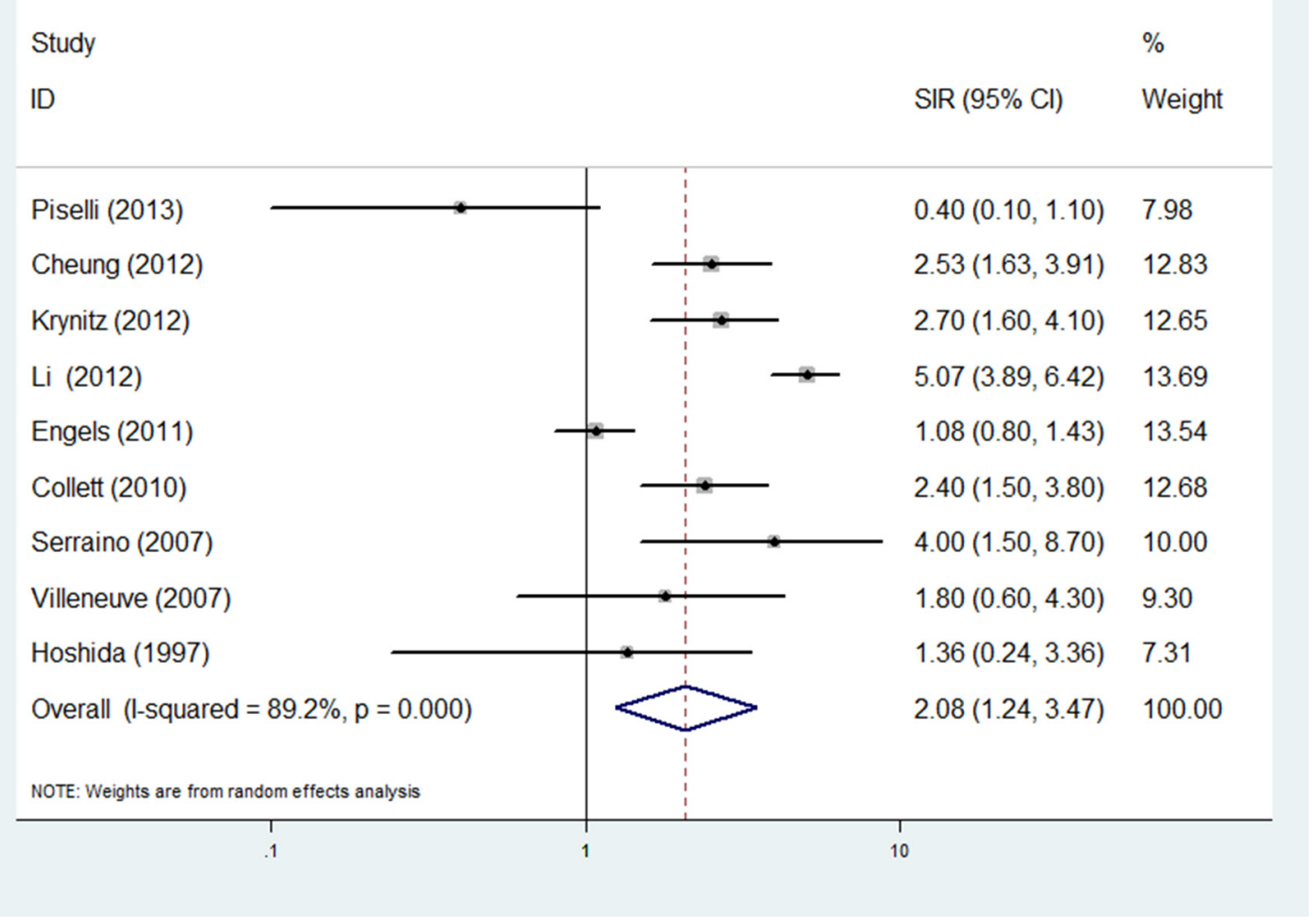

Figure 2: Forest plots of the relative ratios (RRs) and $95 \%$ confidence intervals (CIs) for overall risk of liver cancer. The squares and horizontal lines correspond to the study-specific RR and 95\% CI. The area of the squares reflects the study specific weight. 
Table 4: Sensitivity analysis

\begin{tabular}{lllll}
\hline \multirow{2}{*}{ Study } & Year & SIR & 95\% Confidence intervals & UCI \\
\hline Piselli & 2013 & & 1.439 & 4.003 \\
Cheung & 2012 & 2.400 & 1.101 & 3.623 \\
Krynitz & 2012 & 1.997 & 1.101 & 3.571 \\
Li & 2012 & 1.982 & 1.209 & 2.814 \\
Engels & 2011 & 1.844 & 1.579 & 3.733 \\
Collett & 2010 & 2.428 & 1.117 & 3.635 \\
Serraino & 2007 & 2.015 & 1.111 & 3.341 \\
Villeneuve & 2007 & 1.926 & 1.215 & 3.642 \\
Hoshida & 1997 & 2.103 & 1.253 & 3.675 \\
Combined & - & 2.146 & $\mathbf{1 . 2 4 4}$ & $\mathbf{3 . 4 7 1}$ \\
\hline
\end{tabular}

HBV infection is special infected situation in the human body $[37,38]$. Occult hepatitis B infection(OBI) is the presence of hepatitis B virus (HBV) DNA in serum or hepatic tissue without detectable hepatitis B virus surface antigen (HBsAg) in serum [39]. Occult hepatitis $\mathrm{B}$ infection may be reactivated, then resulting in acute and severe patterns of hepatitis B virus, which may also occur after transmission of OBI by transfusion or organ transplant. Immunosuppressed and cirrhotic individuals with OBI prone to viral reactivation and hepatocellular transformation [37], so it requires the usage of highly sensitive and specific molecular biology techniques. In the human body, some patients are involved in the immunosuppression situation with acquired immune deficiency such as those with HIV and AIDS (especially HIV popular region). Although the majority of the elevated site-specific cancer risks appear to be driven mostly by immune suppression, linked with oncogenic viral or bacterial infections [40], tumor-promoting effects of the immunosuppressive drugs themselves may also contribute [41]. The long term use of immunosuppressive therapy for the graft is another possible factor promoting liver cancer, as reported for other malignancies $[17,22$, 42]. Indeed, immunosuppression resulting from inherited deficiency, AIDS or drugs, has been associated with a higher risk of malignancy than in a immunocompetent population [43]. Immunosuprssive regiments such as azathioprine, prednisolone and cyclosporine have been used commonly in recent decades and carry similar risks for carcinogenicity after kidney transplantation [44]. The exact mechanism for carcinogenicity is unknown. It potentially produces the cytokines that regulate tumor growth, metastasis and angiogenesis. In addition, azathioprine also impair the ability to repair the genetic slicing through acting on the DNA and RNA ways [45]. Other studies have found that the use of mTORi may reduce the overall risk of solid cancers in $\mathrm{KT}$ recipients
$[15,45]$. Among latent infection patients, it is necessary to adjust the dose of immunosuppressant agents according to the patients' post-operation situation. Some studies also reported other known factors such as age, sex, history of smoking, underlying disease leading to transplantation and history of prior cancers, these known factors maybe influence deeply for the transplant recipients [44, 46]. For instance, if the recipients had a history of alcoholic liver cirrhosis, while in the study without excluding from the transplants, thus increasing the frequency of KT recipients at higher risk of liver cancer.

There are some limitations in this meta-analysis. 1) Despite the funnel plot and Egger's test showed the absence of publication bias, some important studies except for English publications or unpublished date related to our studies may have been missed, especially when the pooled increased estimate for liver cancer after transplantation was generated from the limited publications. 2) This meta-analysis included several different genetic background, medical situation, life styles, no detailed information for us to perform an adjustment for these potential confounders, such as the period of chronic hepatitis virus carrier, the period of alcoholic liver cirrhosis, obesity and so on. 3) In our collected data, although all studies used the general population as the reference population, the criteria used for matching might be different applied, 4) In our screened studies, two important indices, mean age at diagnosis of malignancy and mean time to develop liver cancer, were not measured in the included studies. 5) The renal transplant recipients were not screened for liver cancer before kidney transplantation (especially chronic hepatitis virus carrier). What's more, the length of time from transplantation to the diagnosis of the liver cancer was not clear in our results. So we could not exclude the recipients of possible pre-existing tumors in these recipients. 6) Related information on the type 


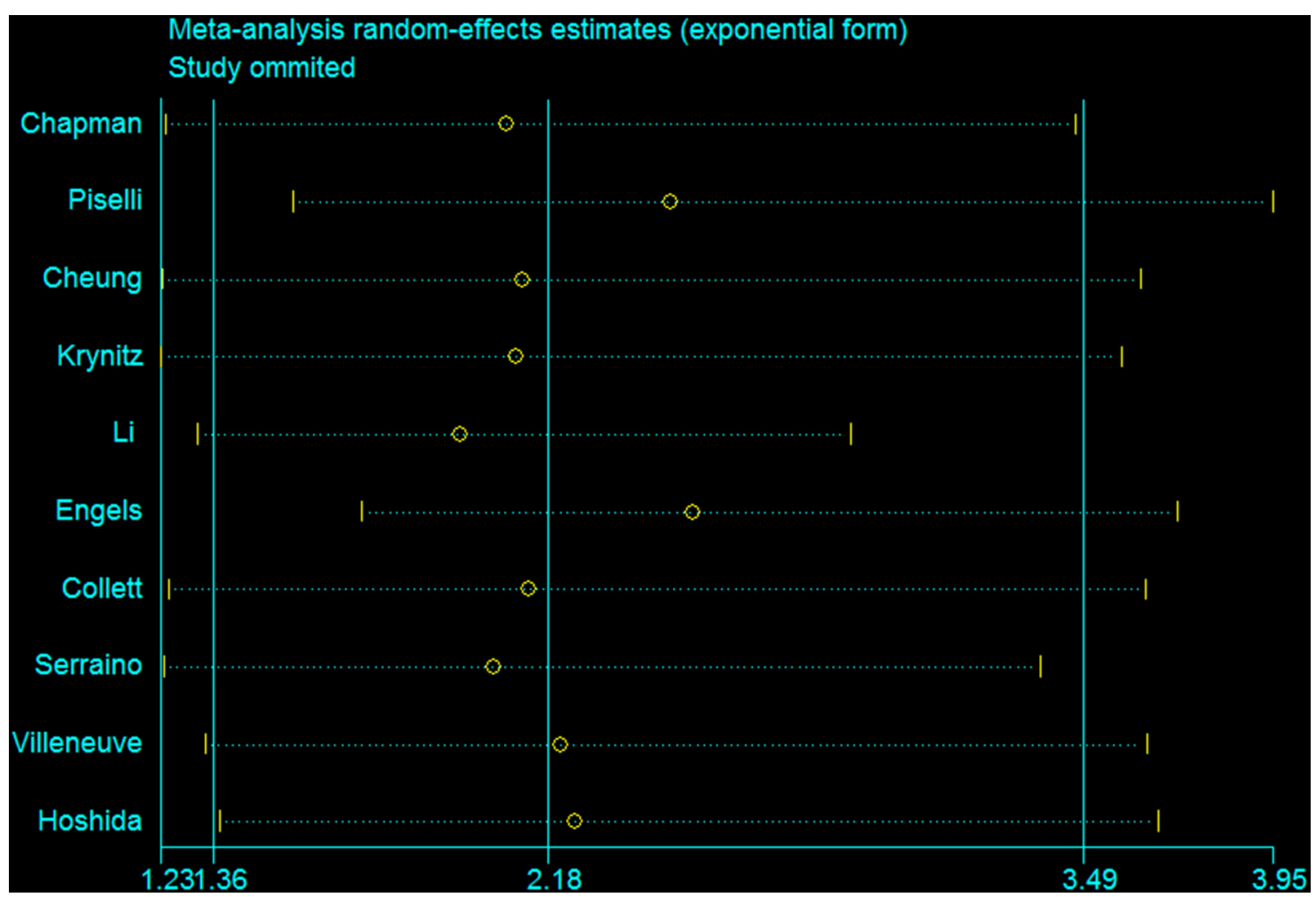

Figure 3: Results of sensitivity analysis liver cancer risk in renal transplant recipients.

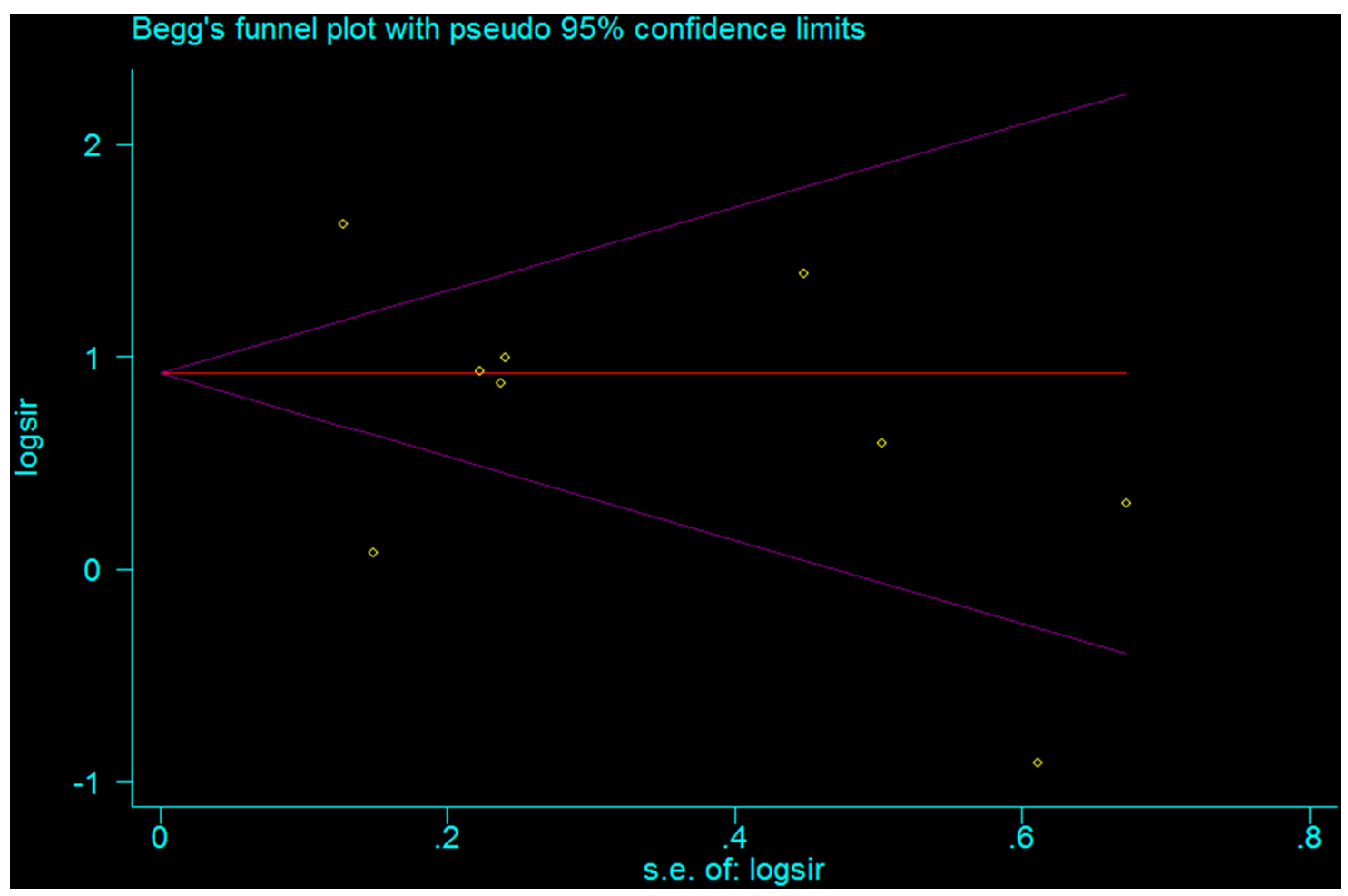

Figure 4: Begg's funnel plots of liver cancer risk across all related populations. 
and the dosage of immunosuppressive agents were not available for the further subgroup analysis. Some studies demonstrated that low-dose cyclosporine was associated with a lower rate of malignancy than highdose cyclosporine in RTRs [47].

\section{MATERIALS AND METHODS}

\section{Literature search}

In designing our meta-analysis, a systematic and comprehensive PubMed literature search and Web of Science Databases search updated through September 2015 was conducted to identify studies involving the risk of liver cancer in renal transplantation recipients. The search was restricted to studies published in English and to those including only humans. Search key terms used were 'renal transplantation', 'kidney transplantation', 'liver' and 'cancer'. The search results were restricted to the presence of the key terms in the title, abstracts and unpublished reports were excluded.

\section{Inclusion and exclusion criteria}

Eligible studies were selected for meta-analysis if they conform to the following inclusion criteria:(1) studies must be population-based cohort studies in renal transplantation recipients; (2) SIR were calculated with $95 \%$ confidence intervals in transplant recipients as compared to the general population. (3) Sufficient data on the incidence rate, SIR or relative risk (RR) of liver cancer and enough numbers of patients should be included in the studies. The following exclusion criteria were used: (1) other organ transplantation studies; (2) they were case series, case-control studies, or case reports; (3) they evaluated liver cancer following transplantation of organs other than the kidney; or (4) they evaluated cancers other than liver cancer following renal transplantation.

\section{Data extraction}

The final date from all qualified publication were independently by two investigators (PC and TW) using the inclusion criteria above. They reached an agreement on all items after reducing any form of bias. Important information extracted from each study included: the first author, publication year, the type of transplantation, data source, geographic origin, number of patients, number of renal transplantation cases, length of follow-up time, number of all cancers in kidney transplant cases, mean follow-up time(years), patients-years(years), mean age at transplantation(years), number of expected cases of liver cancer, number of identified cases of liver cancer, and the SIRs of commonly known cancers and liver cancer.

\section{Statistical analysis}

In this meta-analysis, we obtained an estimate from each study of the unadjusted relative risk (RR) with $95 \%$ confidence intervals (CIs) to assess the strength of liver cancer in renal transplantation recipients compared to the general population. Because of possible heterogeneity in our studies, a random-effects model was used to pool effects for RR [48]. Heterogeneity between studies, namely differences in study outcomes, was calculated using the chi-squared-based Q-statistic test. The models of analysis for the pooled RRs were based on the $\mathrm{P}$ value. By estimating $I^{2}$, which was documented for the percentage of the observed between study variability due to heterogeneity rather than chance, with $I^{2}<25 \%, 25 \%$ $75 \%$ and $>75 \%$ representing low, moderate and high degree of inconsistency, respectively.

We assessed the effects of individual study data on the pooled RR through one-way sensitivity analysis. After the sequential removal of each study, the remaining studies could be used to evaluate the stability of the results. At the same time, we assessed publication bias by using a funnel plot and Begg's test to find out whether there was a bias towards publication of studies [49]. Funnel plot asymmetry was assessed using Egger's linear regression method on the natural logarithm scale of the RR. A symmetric plot suggested publication bias, with a $P$ value $<0.05$ indicating significant publication bias. All statistical analyses were performed using the STATE 11.0 software (version 11; STATA Corp, college station, TX, USA).

\section{CONCLUSIONS}

In conclusion, our meta-analysis showed an increased risk of developing liver carcinoma in transplant recipients (especially chronic hepatitis virus carrier). Renal transplant recipients should therefore be screened cautiously for their liver function and adjusted the dosage or period of immunosuppresive agents according to patients' clinical examination results. If they are the recipients with chronic hepatitis, periodic ultrasound and alpha fetoprotein monitering every 6-12 months are recommended among chronic hepatitis carriers because early detection of tumor can have a higher chance of receiving treatment [50].

\section{Author contributions}

These authors contributed equally to this work.

\section{ACKNOWLEDGMENTS}

We acknowledge that Northern Jiangsu People's Hospital, Yangzhou University for supporting the work of our study. 


\section{CONFLICTS OF INTEREST}

The authors have declared that no competing interests exist.

\section{FUNDING}

None.

\section{REFERENCES}

1. Thawornchaisit P, de Looze F, Reid CM, Seubsman SA, Tran TT, Sleigh A; Thai Cohort Study T. Health-risk factors and the prevalence of chronic kidney disease: cross-sectional findings from a national cohort of 87,143 Thai Open University Students. Glob J Health Sci. 2015; 7:59-72.

2. Noborisaka Y, Ishizaki M, Yamada Y, Honda R, Yokoyama $\mathrm{H}$, Miyao M, Tabata M. Distribution of and factors contributing to chronic kidney disease in a middle-aged working population. Environ Health Prev Med. 2013; 18:466-476.

3. Ponte B, Pruijm M, Marques-Vidal P, Martin PY, Burnier M, Paccaud F, Waeber G, Vollenweider P, Bochud M. Determinants and burden of chronic kidney disease in the population-based CoLaus study: a cross-sectional analysis. Nephrol Dial Transplant. 2013; 28:2329-2339.

4. Keith DS, Nichols GA, Gullion CM, Brown JB, Smith DH. Longitudinal follow-up and outcomes among a population with chronic kidney disease in a large managed care organization. Arch Intern Med. 2004; 164:659-663.

5. Chronic Kidney Disease Prognosis C, Matsushita K, van der Velde M, Astor BC, Woodward M, Levey AS, de Jong PE, Coresh J, Gansevoort RT. Association of estimated glomerular filtration rate and albuminuria with all-cause and cardiovascular mortality in general population cohorts: a collaborative meta-analysis. Lancet. 2010; 375:2073-2081.

6. Suthanthiran M, Strom TB. Renal transplantation. N Engl J Med. 1994; 331:365-376.

7. Buell JF, Gross TG, Woodle ES. Malignancy after transplantation. Transplantation. 2005; 80:S254-264.

8. Knight SR, Russell NK, Barcena L, Morris PJ. Mycophenolate mofetil decreases acute rejection and may improve graft survival in renal transplant recipients when compared with azathioprine: a systematic review. Transplantation. 2009; 87:785-794.

9. O'Grady JG, Burroughs A, Hardy P, Elbourne D, Truesdale A; UK and Republic of Ireland Liver Transplant Study Group. Tacrolimus versus microemulsified ciclosporin in liver transplantation: the TMC randomised controlled trial. Lancet. 2002; 360:1119-1125.

10. Penn I. Cancers in renal transplant recipients. Adv Ren Replace Ther. 2000; 7:147-156.
11. Kauffman HM, Cherikh WS, McBride MA, Cheng Y, Hanto DW. Post-transplant de novo malignancies in renal transplant recipients: the past and present. Transpl Int. 2006; 19:607-620.

12. Montalto G, Cervello M, Giannitrapani L, Dantona F, Terranova A, Castagnetta LA. Epidemiology, risk factors, and natural history of hepatocellular carcinoma. Ann N Y Acad Sci. 2002; 963:13-20.

13. Cheung CY, Lam MF, Chu KH, Chow KM, Tsang KY, Yuen SK, Wong PN, Chan SK, Leung KT, Chan CK, Ho YW, Chau KF. Malignancies after kidney transplantation: Hong Kong renal registry. Am J Transplant. 2012; 12:3039-3046.

14. Wynia A. A human services advocate. Interview by Richard L. Reece. Minn Med. 1990; 73:11-14.

15. Piselli P, Serraino D, Segoloni GP, Sandrini S, Piredda GB, Scolari MP, Rigotti P, Busnach G, Messa P, Donati D, Schena FP, Maresca MC, Tisone G, et al. Risk of de novo cancers after transplantation: results from a cohort of 7217 kidney transplant recipients, Italy 1997-2009. Eur J Cancer. 2013; 49:336-344.

16. Krynitz B, Edgren G, Lindelof B, Baecklund E, Brattstrom C, Wilczek H, Smedby KE. Risk of skin cancer and other malignancies in kidney, liver, heart and lung transplant recipients 1970 to 2008--a Swedish population-based study. Int J Cancer. 2013; 132:1429-1438.

17. Li WH, Chen YJ, Tseng WC, Lin MW, Chen TJ, Chu SY, Hwang CY, Chen CC, Lee DD, Chang YT, Wang WJ, Liu HN. Malignancies after renal transplantation in Taiwan: a nationwide population-based study. Nephrol Dial Transplant. 2012; 27:833-839.

18. Engels EA, Pfeiffer RM, Fraumeni JF Jr, Kasiske BL, Israni AK, Snyder JJ, Wolfe RA, Goodrich NP, Bayakly AR, Clarke CA, Copeland G, Finch JL, Fleissner ML, et al. Spectrum of cancer risk among US solid organ transplant recipients. JAMA. 2011; 306:1891-1901.

19. Collett D, Mumford L, Banner NR, Neuberger J, Watson C. Comparison of the incidence of malignancy in recipients of different types of organ: a UK Registry audit. Am J Transplant. 2010; 10:1889-1896.

20. Serraino D, Piselli P, Busnach G, Burra P, Citterio F, Arbustini E, Baccarani U, De Juli E, Pozzetto U, Bellelli S, Polesel J, Pradier C, Dal Maso L, et al. Risk of cancer following immunosuppression in organ transplant recipients and in HIV-positive individuals in southern Europe. Eur J Cancer. 2007; 43:2117-2123.

21. Villeneuve PJ, Schaubel DE, Fenton SS, Shepherd FA, Jiang Y, Mao Y. Cancer incidence among Canadian kidney transplant recipients. Am J Transplant. 2007; 7:941-948.

22. Hoshida Y, Tsukuma H, Yasunaga Y, Xu N, Fujita MQ, Satoh T, Ichikawa Y, Kurihara K, Imanishi M, Matsuno T, Aozasa K. Cancer risk after renal transplantation in Japan. Int J Cancer. 1997; 71:517-520.

23. Vajdic CM, McDonald SP, McCredie MR, van Leeuwen MT, Stewart JH, Law M, Chapman JR, Webster AC, Kaldor 
JM, Grulich AE. Cancer incidence before and after kidney transplantation. JAMA. 2006; 296:2823-2831.

24. Andres A. Cancer incidence after immunosuppressive treatment following kidney transplantation. Crit Rev Oncol Hematol. 2005; 56:71-85.

25. Hwang EA, Kang MJ, Han SY, Park SB, Kim HC. Viral infection following kidney transplantation: long-term follow-up in a single center. Transplant Proc. 2004; 36:2118-2119.

26. Huang CC, Liaw YF, Lai MK, Chu SH, Chuang CK, Huang JY. The clinical outcome of hepatitis $\mathrm{C}$ virus antibodypositive renal allograft recipients. Transplantation. 1992; 53:763-765.

27. Berthoux F. Hepatitis $\mathrm{C}$ virus infection and disease in renal transplantation. Nephron. 1995; 71:386-394.

28. Legendre C, Garrigue V, Le Bihan C, Mamzer-Bruneel MF, Chaix ML, Landais P, Kreis H, Pol S. Harmful long-term impact of hepatitis $\mathrm{C}$ virus infection in kidney transplant recipients. Transplantation. 1998; 65:667-670.

29. Mathurin P, Mouquet C, Poynard T, Sylla C, Benalia H, Fretz C, Thibault V, Cadranel JF, Bernard B, Opolon P, Coriat $\mathrm{P}$, Bitker MO. Impact of hepatitis $\mathrm{B}$ and $\mathrm{C}$ virus on kidney transplantation outcome. Hepatology. 1999; 29:257-263.

30. Hanafusa T, Ichikawa Y, Kishikawa H, Kyo M, Fukunishi T, Kokado Y, Okuyama A, Shinji Y, Nagano S. Retrospective study on the impact of hepatitis $\mathrm{C}$ virus infection on kidney transplant patients over 20 years. Transplantation. 1998; 66:471-476.

31. Chan TM, Lok AS, Cheng IK. Hepatitis C in renal transplant recipients. Transplantation. 1991; 52:810-813.

32. Klauser R, Franz M, Traindl O, Pidlich J, Hay U, Watschinger B, Pohanka E, Kovarik J. Hepatitis C antibody in renal transplant patients. Transplant Proc. 1992; 24:286-288.

33. Petrosillo N, Puro V, Ippolito G. Prevalence of human immunodeficiency virus, hepatitis B virus and hepatitis $\mathrm{C}$ virus among dialysis patients. The Italian Multicentric Study on Nosocomial and Occupational Risk of BloodBorne Infections in Dialysis. Nephron. 1993; 64:636-639.

34. Cody J, Daly C, Campbell M, Donaldson C, Khan I, Rabindranath K, Vale L, Wallace S, Macleod A. Recombinant human erythropoietin for chronic renal failure anaemia in pre-dialysis patients. Cochrane Database Syst Rev. 2005; CD003266.

35. Offord DR, Boyle MH, Racine Y, Szatmari P, Fleming JE, Sanford M, Lipman EL. Integrating assessment data from multiple informants. J Am Acad Child Adolesc Psychiatry. 1996; 35:1078-1085.
36. Fabrizi F, Martin P, Ponticelli C. Hepatitis C virus infection and renal transplantation. Am J Kidney Dis. 2001; 38:919-934.

37. Squadrito G, Spinella R, Raimondo G. The clinical significance of occult HBV infection. Ann Gastroenterol. 2014; 27:15-19.

38. Romero M, Madejon A, Fernandez-Rodriguez C, GarciaSamaniego J. Clinical significance of occult hepatitis B virus infection. World J Gastroenterol. 2011; 17:1549-1552.

39. Kwak MS, Kim YJ. Occult hepatitis B virus infection. World J Hepatol. 2014; 6:860-869.

40. Schulz TF. Cancer and viral infections in immunocompromised individuals. Int J Cancer. 2009; 125:1755-1763.

41. Ingvar A, Smedby KE, Lindelof B, Fernberg P, Bellocco R, Tufveson G, Hoglund P, Adami J. Immunosuppressive treatment after solid organ transplantation and risk of posttransplant cutaneous squamous cell carcinoma. Nephrol Dial Transplant. 2010; 25:2764-2771.

42. Sampaio MS, Cho YW, Qazi Y, Bunnapradist S, Hutchinson IV, Shah T. Posttransplant malignancies in solid organ adult recipients: an analysis of the U.S. National Transplant Database. Transplantation. 2012; 94:990-998.

43. Penn I. Why do immunosuppressed patients develop cancer? Crit Rev Oncog. 1989; 1:27-52.

44. Gallagher MP, Kelly PJ, Jardine M, Perkovic V, Cass A, Craig JC, Eris J, Webster AC. Long-term cancer risk of immunosuppressive regimens after kidney transplantation. Journal of the American Society of Nephrology: JASN. 2010; 21:852-858.

45. Chapman JR, Webster AC, Wong G. Cancer in the transplant recipient. Cold Spring Harb Perspect Med. 2013; 3.

46. Webster AC, Craig JC, Simpson JM, Jones MP, Chapman JR. Identifying high risk groups and quantifying absolute risk of cancer after kidney transplantation: a cohort study of 15,183 recipients. Am J Transplant. 2007; 7:2140-2151.

47. Dantal J, Hourmant M, Cantarovich D, Giral M, Blancho G, Dreno B, Soulillou JP. Effect of long-term immunosuppression in kidney-graft recipients on cancer incidence: randomised comparison of two cyclosporin regimens. Lancet. 1998; 351:623-628.

48. DerSimonian R, Kacker R. Random-effects model for metaanalysis of clinical trials: an update. Contemp Clin Trials. 2007; 28:105-114.

49. Egger M, Davey Smith G, Schneider M, Minder C. Bias in meta-analysis detected by a simple, graphical test. BMJ. 1997; 315:629-634.

50. Yuen MF, Cheng CC, Lauder IJ, Lam SK, Ooi CG, Lai CL. Early detection of hepatocellular carcinoma increases the chance of treatment: Hong Kong experience. Hepatology. 2000; 31:330-335.. 